\title{
APLIKASI GEOFOAM SEBAGAI MATERIAL TIMBUNAN DI ATAS TANAH LUNAK
}

\author{
Irpan Hidayat; Andryan Suhendra \\ Jurusan Teknik Sipil, Fakultas Sains dan Teknologi, Binus University \\ Jl. KH. Syahdan No. 9, Palmerah, Jakarta Barat 11480. \\ irpan@binus.edu; asuhendra@binus.edu
}

\begin{abstract}
Geofoam is a geosintetik material made of Expanded Polystyrene (EPS) and Xtruded Polystyrene (XPS), which has a low weight property which makes geofoam widely used as a lightweight fill material and has been applied in Europe, especially in Eastern Europe. This is a preliminary research that emphasizes on the use of geofoam as a fill material on soft ground through theoretical analysis using Plaxis program. Supporting data used covers data of basic and fill ground taken from specific locations which are planned for subsequent research as a field test. Based on the Plaxis program results, the use of geofoam as a fill material give a higher safety factor value with a smaller deformation compared to laterite soil. This result indicates that the use of geofoam as a fill material can be considered to be applied in the country.
\end{abstract}

Keywords: geofoam, lightweight fill material, soft ground, plaxis.

\begin{abstract}
ABSTRAK
Geofoam merupakan salah satu material geosintetik yang terbuat dari Expanded Polystyrene (EPS) dan Xtruded Polystyrene (XPS) yang mempunyai properti berat yang rendah. Keunggulan ini menjadikan geofoam banyak digunakan sebagai material timbunan yang ringan dan sudah diaplikasikan di Eropa terutama Eropa Timur. Penelitian ini merupakan penelitian awal yang menitikberatkan penggunaan geofoam sebagai material timbunan di atas tanah lunak melalui analisis teoritis menggunakan program Plaxis. Data-data pendukung yang digunakan mencakup data tanah dasar dan timbunan yang diambil dari lokasi tertentu yang akan digunakan untuk penelitian selanjutnya berupa uji lapangan. Berdasarkan hasil dari program Plaxis, penggunaan geofoam sebagai material timbunan memberikan nilai faktor keamanan yang lebih tinggi dengan nilai deformasi yang lebih kecil jika dibandingkan dengan tanah laterit. Hasil ini menunjukkan bahwa penggunaan geofoam sebagai material timbunan dapat dipertimbangkan untuk diaplikasikan di dalam negeri.
\end{abstract}

Kata kunci: geofoam; material timbunan ringan; tanah lunak; plaxis 


\section{PENDAHULUAN}

Sebagai negara yang sedang berkembang, Indonesia membutuhkan banyak pembangunan termasuk pembangunan infrastruktur seperti konstruksi jalan sebagai jalur distribusi dalam memeratakan pembangunan. Namun, kondisi tanah dasar yang relatif lunak menimbulkan banyak masalah baik dalam proses pembangunan maupun masa pelayanan konstruksi jalan tersebut. Beberapa permasalahan yang umum ditemukan pada konstruksi jalan atau timbunan di atas tanah lunak di antaranya adalah masalah stabilitas timbunan dan masalah penurunan konsolidasi yang besar dalam waktu yang relatif lama. Ada berbagai metode penanggulangan yang dapat dan telah diterapkan seperti perbaikan tanah dasar menggunakan metode statik (prabeban, percepatan konsolidasi dengan vertical drain, perkuatan dengan material geosintetik), metode dinamik (dynamic compaction, vibro compaction) dan stabilisasi kimiawi (jet grouting, deep soil mixing). Metode lain yang perlu dipertimbangkan adalah penggunaan material timbunan yang ringan yaitu geofoam yang sudah banyak diaplikasikan di Eropa terutama Eropa Timur sejak 25 tahun yang lalu.

\section{Material Geofoam}

Geofoam merupakan salah satu material geosintetik yang dibuat dari polimer Expanded Polystyrene (EPS) dan Xtruded Polystyrene (XPS). EPS merupakan polimer yang banyak digunakan sebagai pembungkus dan konstruksi bangunan. Pembuatan balok EPS dimulai dari butir-butir resin berdiameter kurang dari $3 \mathrm{~mm}$ dan berisi sel mikroskopik mengandung zat pengembang (pentanes atau butanes sekitar 5\% dari berat butir resin). Saat terpapar uap air bertekanan, dinding sel menjadi lunak dan zat pengembang akan memuai. Setiap butir resin akan memuai hingga 40 kali volume awal untuk membentuk suatu gumpalan. Setelah terstabilisasi beberapa saat pada suhu kamar, gumpalangumpalan tersebut dituangkan ke dalam cetakan berbentuk balok.Gumpalan-gumpalan di dalam cetakan memuai lebih lanjut dan melebur membentuk balok. Material geofoam harus dibuat dari butirbutir yang telah dimodifikasi yang mengandung aditif penghambat kebakaran (fire retardant). Umumnya balok EPS dibuat dengan densitas dan dimensi tertentu mengikuti peraturan ASTM C-578 seperti pada tabel 1 dan 2 berikut ini.

Tabel 1

Densitas Balok EPS Menurut ASTM C-578

\begin{tabular}{|c|c|}
\hline Tipe & Densitas $\left(\mathrm{kg} / \mathrm{m}^{3}\right)$ \\
\hline I & 15 \\
\hline II & 22 \\
\hline VIII & 18 \\
\hline IX & 29 \\
\hline XI & 12 \\
\hline
\end{tabular}

Tabel 2

Rentang Ukuran Standar Balok EPS

\begin{tabular}{lc}
\hline \multicolumn{1}{c}{ Dimensi } & ukuran $(\mathbf{m m})$ \\
\hline Panjang & $1219-4877$ \\
Lebar & $305-1219$ \\
Tinggi & $9,5-610$ \\
\hline
\end{tabular}

Ukuran dan bentuk lain (selain balok) juga dimungkinkan dengan cara mengatur tekanan dan bentuk cetakan serta dengan cara dipotong. 
Sedangkan pembuatan geofoam XPS mulai dari butir polystyrene yang dilumerkan dan dicampur dengan aditif tertentu untuk membentuk campuran yang kental. Zat pengembang kemudian dinjeksi ke dalam campuran tadi untuk keperluan pemuaian. Melalui pengontrolan suhu dan tekanan, campuran kemudian dibentuk dengan tekanan tertentu untuk mendapatkan bentuk yang diinginkan yang kemudian dipotong menjadi ukuran akhir.

Serupa dengan balok EPS, umumnya balok XPS juga dibuat dengan densitas dan dimensi tertentu mengikuti peraturan ASTM C-578 seperti pada Tabel 3 dan 4 berikut ini.

Tabel 3

Densitas Balok XPS Menurut ASTM C-578

\begin{tabular}{|c|c|}
\hline Tipe & Densitas $\left(\mathrm{kg} / \mathrm{m}^{3}\right)$ \\
\hline IV & 26 \\
\hline V & 48 \\
\hline VI & 29 \\
\hline VII & 35 \\
\hline $\mathrm{X}$ & 22 \\
\hline
\end{tabular}

Tabel 4

Rentang Ukuran Standar Balok XPS

\begin{tabular}{lc}
\hline \multicolumn{1}{c}{ Dimensi } & ukuran $(\mathbf{m m})$ \\
\hline Panjang & $1219-2743$ \\
Lebar & $406-1219$ \\
Tinggi & $13-102$ \\
\hline
\end{tabular}

Kedua jenis geofoam di atas umumnya sebagai material insulasi dan material timbunan yang ringan serta dapat digunakan kembali sekalipun telah tertanam hingga belasan tahun.

Keunggulan lain dari material geofoam ini adalah material ini dapat di daur ulang tanpa memerlukan proses kimia dan ramah lingkungan.

Tabel 4

Perbandingan Densitas Geofoam dan Material Lain

\begin{tabular}{lr}
\hline \multicolumn{1}{c}{ Material } & Density $\left(\mathbf{k g} / \mathbf{c m}^{3}\right)$ \\
\hline Bark $^{1}$ & $1000-1100$ \\
Sawdust $^{1}$ & 1000 \\
Cellular concrete waste $^{1}$ & 1000 \\
Light expanded clay (Leca) $^{1}$ & $800-1000$ \\
Waste bricks of Leca $^{1}$ & 1000 \\
Tires $^{2}$ & $700-950$ (in-place) \\
Purnice $^{3}$ & 1225 \\
EPS Geofoam $^{4}$ & $15-120$ \\
\hline
\end{tabular}

Sumber:

${ }^{1}$ Rygg, N., Sorlie, A., (1981). "Plastic Foam in Road Embankments." Soil Mechanics Conference, Stockholm.

${ }^{2}$ Humphrey, D.N., Dunn, P.A., and Merfeld, P.S. (2000). "Tire Shreds Save Money for Maine." TR News, No. 206, January-February, 2000.

${ }^{3}$ Holtz, R.D. and Schuster, R.L., (1996). Stabilization of Soil Slopes. In: Landslides Investigation and Mitigation. Transportation Research Board Special Report 247. National Academy Press, Washington, D.C., p. 429-473.

${ }^{4}$ Dependent on drainage conditions and nominal geofoam density 


\section{Aplikasi Geofoam}

Berikut ini adalah beberapa aplikasi dari material geofoam yang sudah diterapkan di beberapa negara.

Pertama, stabilisasi lereng. Salah satu penyebab kelongsoran pada lereng adalah timbunan yang terlalu berat untuk dapat dipikul baik oleh tanah timbunan itu sendiri maupun oleh tanah dasar. Penggunaan geofoam dengan densitas yang relatif rendah merupakan salah satu solusi yang telah memberikan hasil yang cukup memuaskan.

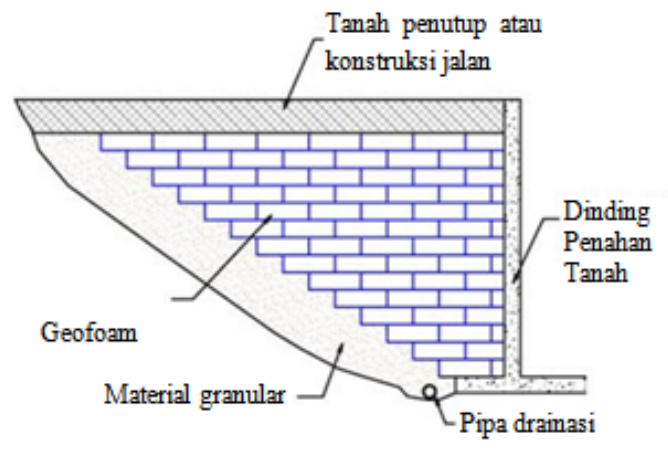

Gambar 2. Aplikasi geofoam sebagai material timbunan di belakang dinding penahan tanah. (sumber : Geofoam Research Center)

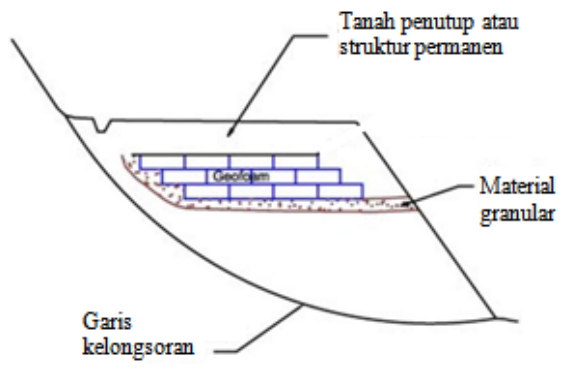

Gambar 3. Aplikasi geofoam sebagai material pengisi badan lereng (sumber : Geofoam Research Center)

Kedua, material timbunan. Rendahnya kuat geser tanah dasar dapat menyebabkan terjadinya ketidakstabilan struktur timbunan yang dibangun di atasnya, terutama jika beban timbunan yang terlalu berat untuk dapat dipikul oleh tanah dasar yang lunak. Penggunaan geofoam yang ringan namun kuat merupakan salah satu solusi yang patut untuk dipertimbangkan. Untuk itu, dalam makalah ini akan dipaparkan mengenai analisis penggunaan geofoam sebagai material timbunan di atas tanah lunak.

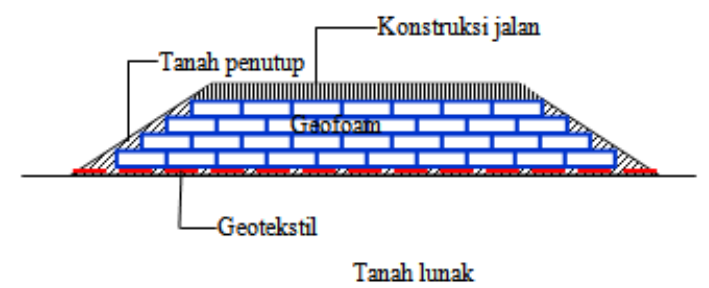

Gambar 4a. Material timbunan dengan geofoam. 


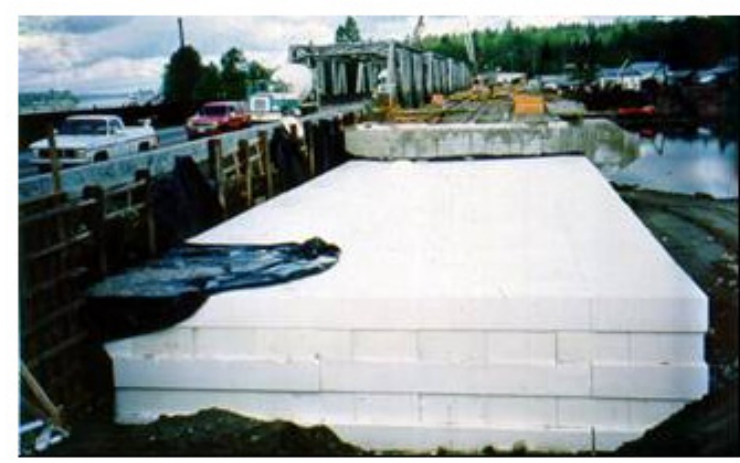

Gambar 4b. Aplikasi geofoam sebagai material timbunan. (sumber : GeoTech Systems Corporation)

Ketiga, penutup permukaan lereng. Pada beberapa kasus penanggulangan kelongsoran lereng dengan perkuatan geosintetik, permukaan lereng yang telah diperkuat perlu diproteksi terhadap kemungkinan kerusakan material geosintetik akibat pengaruh sinar matahari atau akibat vandalisme.

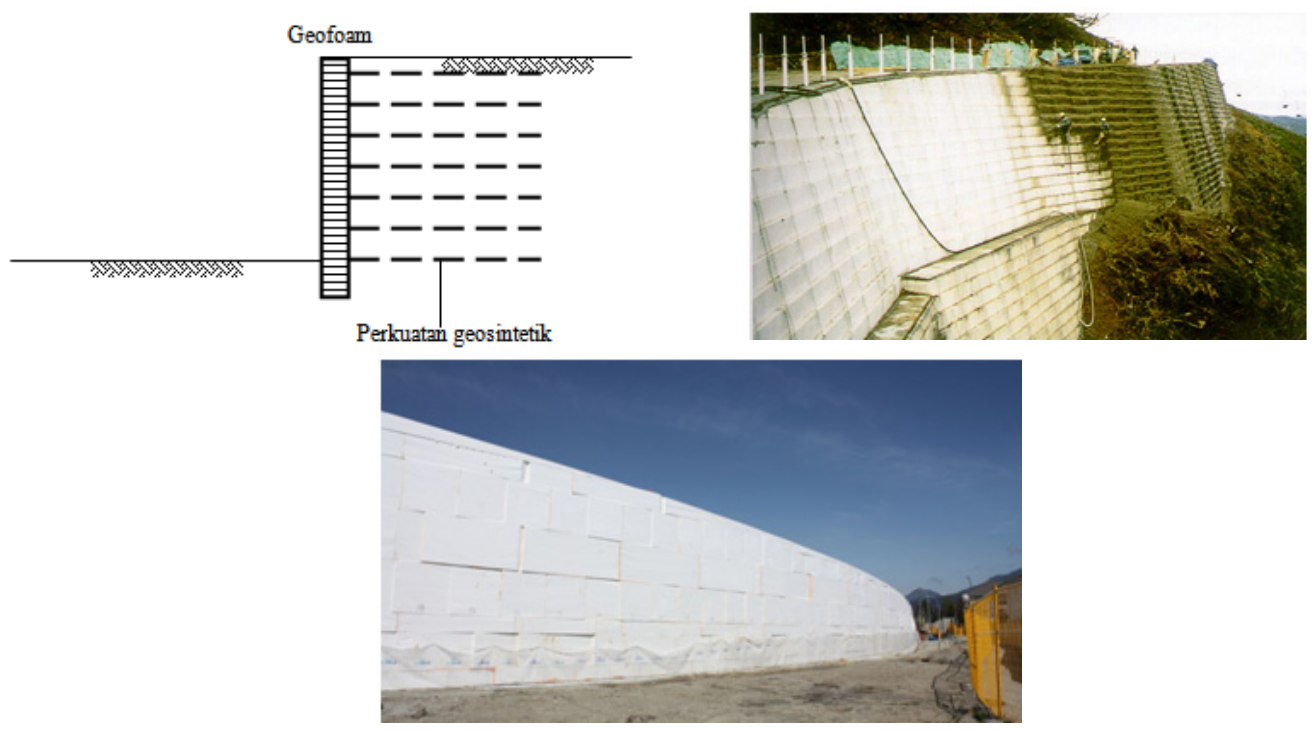

Gambar 5. Aplikasi geofoam sebagai penutup permukaan lereng yang diperkuat dengan material geosintetik.

(sumber : Laudontech)

Keempat, sarana drainasi dan ventilasi di bawah pelat lantai. Pada beberapa daerah dengan kondisi muka air tanah yang tinggi dan sering mengalami kenaikan muka air tanah serta yang mempunyai kandungan gas yang cukup tinggi, penggunaan geofoam merupakan salah satu solusi yang dapat diterapkan untuk menghindari terjadinya genangan air dan tekanan air dan gas di bawah pelat lantai serta temperatur yang dapat menyebabkan kerusakan pada pelat lantai serta mengakibatkan ketidak-nyamanan.

\section{Kondisi dan ruang lingkup penelitian}

Penelitian yang dilakukan merupakan tahap awal dari keseluruhan penelitian yang akan dilakukan, yaitu melakukan analisis secara teoritis konstruksi timbunan menggunakan material 
geofoam yang kemudian akan diperbandingkan dengan konstruksi timbunan yang menggunakan material timbunan yang umum digunakan yaitu tanah laterit.

Analisis teoritis yang akan dilakukan dengan menggunakan bantuan program Plaxis yang berbasis metode elemen hingga.

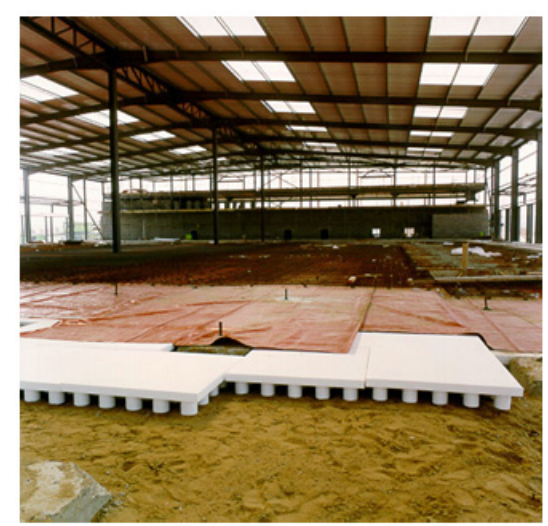

Gambar 6. Aplikasi geofoam sebagai sarana drainasi dan ventilasi di bawah pelat lantai.

\section{Parameter perancangan}

Beberapa parameter perancangan yang digunakan dalam analisis akan menggunakan data-data yang tersedia seperti properti geofoam dan data tanah dasar. Sedangkan untuk data tanah timbunan digunakan properti tanah hasil uji laboratorium. Berikut ini adalah data-data yang akan digunakan dalam analisis menggunakan program Plaxis.

Tabel 5

Properti Geofoam

\begin{tabular}{lr}
\hline \multicolumn{1}{c}{ Properti (standar ASTM) } & \multicolumn{1}{c}{ Nilai } \\
\hline Density (D1622) & $18 \mathrm{~kg} / \mathrm{m}^{3}$ \\
Compressive Resistance (D1621) & $90 \mathrm{kN} / \mathrm{m}^{2}$ \\
Flexural strength (C203) & $208 \mathrm{kN} / \mathrm{m}^{2}$ \\
\hline
\end{tabular}

Tabel 6

Properti Material Timbunan

\begin{tabular}{lr}
\hline \multicolumn{1}{c}{ Properti } & \multicolumn{1}{c}{ Nilai } \\
\hline Unit weight & $1700 \mathrm{~kg} / \mathrm{m}^{3}$ \\
Cohesion & $25 \mathrm{kN} / \mathrm{m}^{2}$ \\
Internal friction angle & $20^{\circ}$ \\
Stiffness modulus & $10000 \mathrm{kN} / \mathrm{m}^{2}$ \\
\hline
\end{tabular}

Sedangkan untuk tanah dasar yang merupakan tanah lempung lunak jenuh air dengan parameter sebagai berikut :

$$
\begin{aligned}
& \gamma=1300 \mathrm{~kg} / \mathrm{m}^{3} \\
& \mathrm{c}=20 \mathrm{kN} / \mathrm{m}^{2} \\
& \phi=0^{\circ} \\
& \mathrm{E}=2000 \mathrm{kN} / \mathrm{m}^{2}
\end{aligned}
$$


Pada penelitian ini diaplikasikan juga beban lalulintas yang dikonversikan menjadi beban merata sebesar 2 ton $/ \mathrm{m}^{2}$.

\section{Plaxis}

Program Plaxis merupakan salah satu program di bidang Geoteknik yang berdasarkan metode elemen hingga. Analisis pada program Plaxis dimulai dari pemodelan geometri, tanah dan lain sebagainya. Material timbunan dan tanah dasar dimodelkan menurut kriteria Mohr-Coulomb.

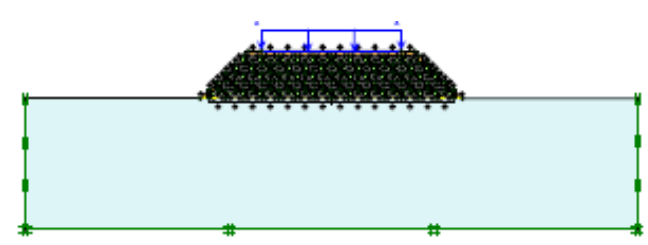

material timbunan : geofoam

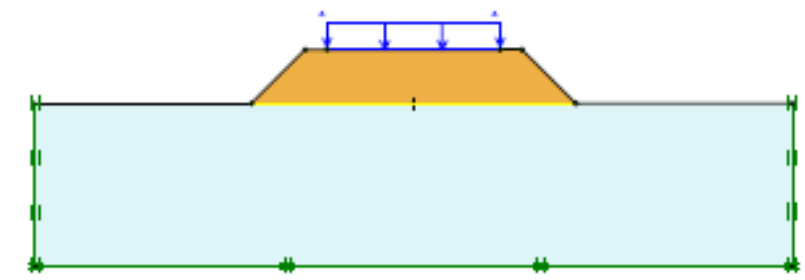

material timbunan : tanah laterit

Gambar 7. Input geometri Plaxis.

\section{HASIL DAN PEMBAHASAN}

Hasil keluaran (output) program Plaxis untuk kedua jenis material timbunan di atas adalah sebagai berikut:

(1) Pola dan besar deformasi (Gambar 8);

(2) Faktor keamanan (Gambar 10);

(3) Kuat tarik perlu geotekstil (Gambar 11)

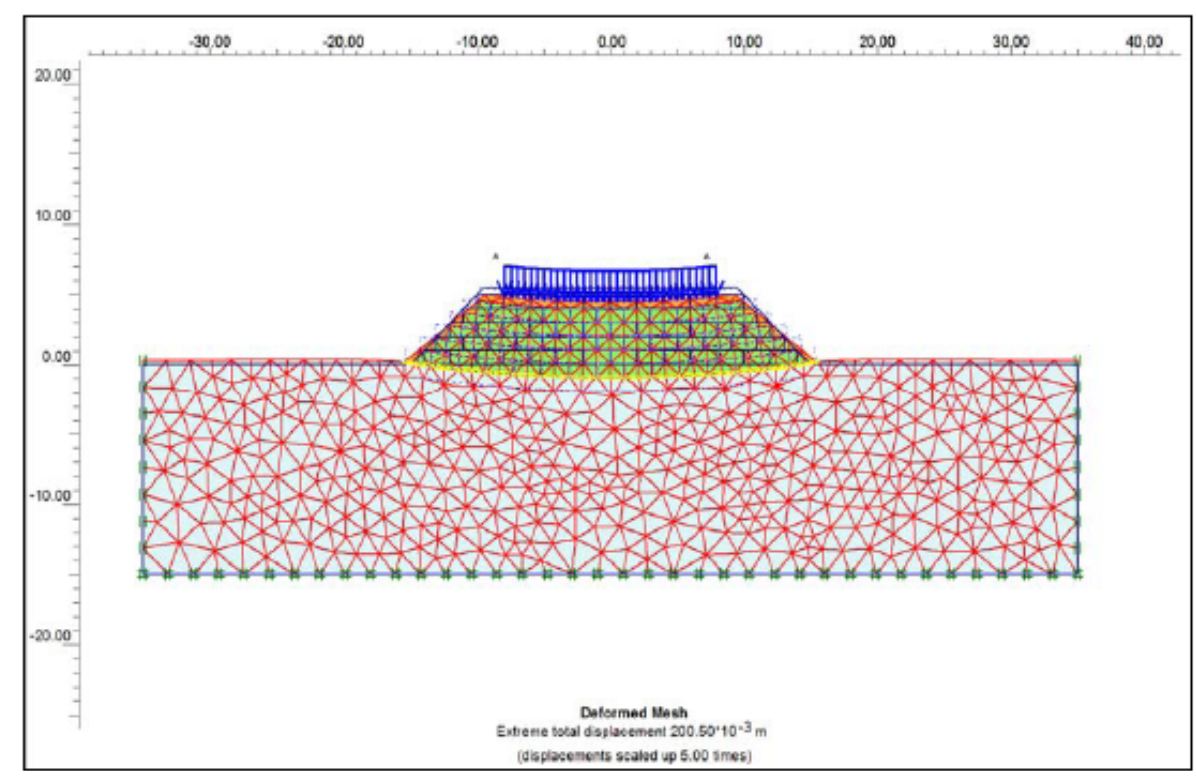




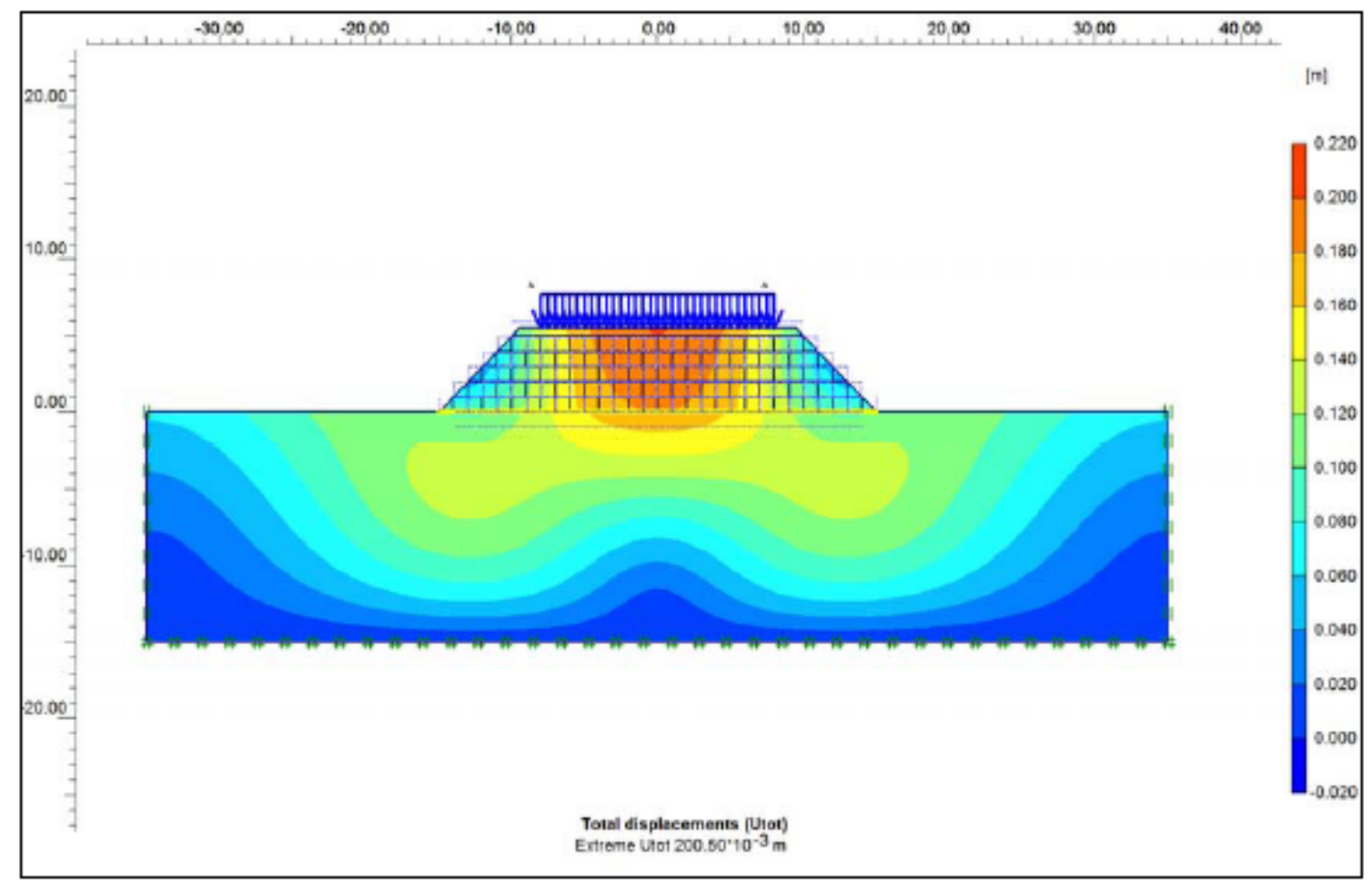

Gambar 8. Pola dan besar displacement konstruksi timbunan geofoam

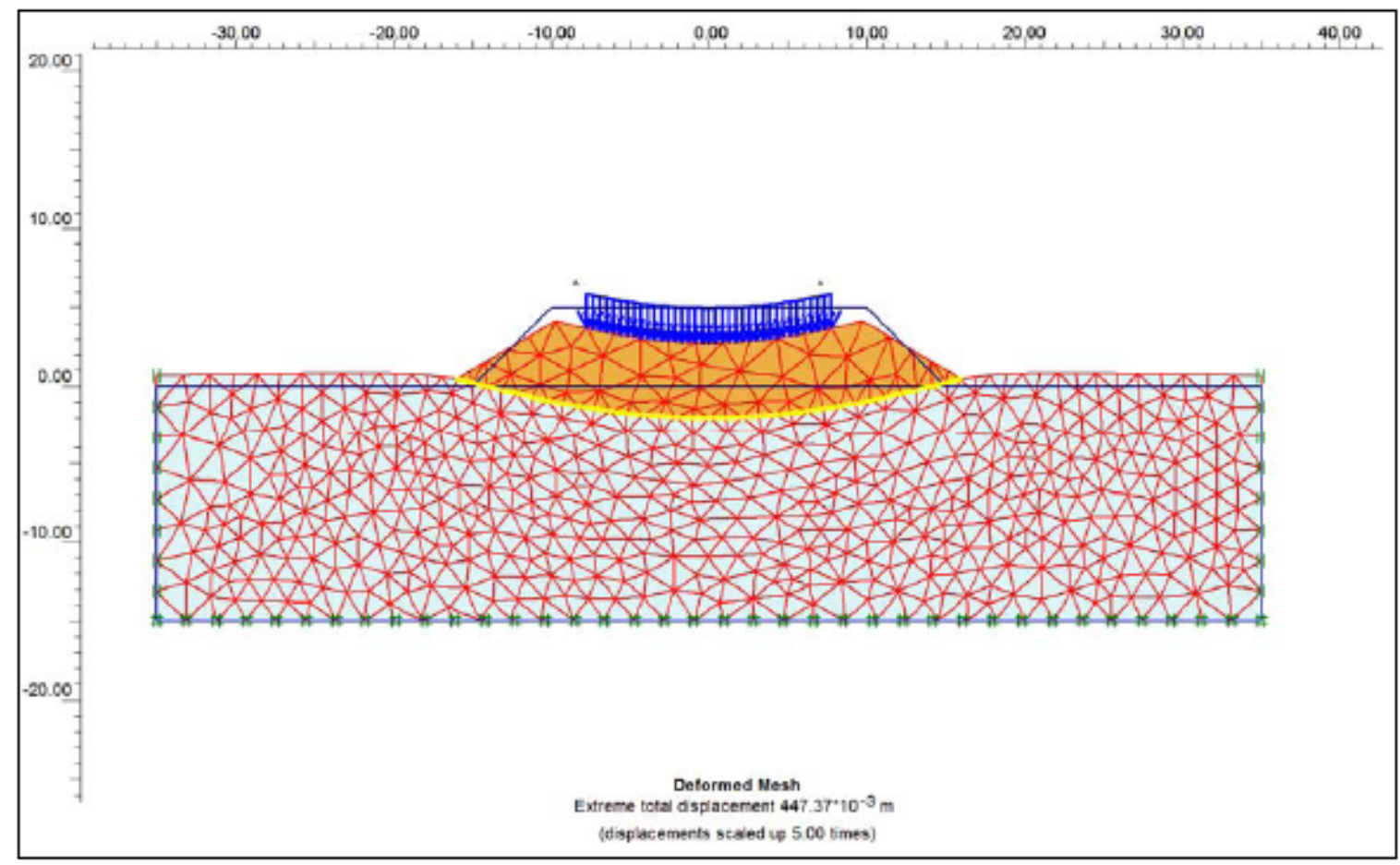




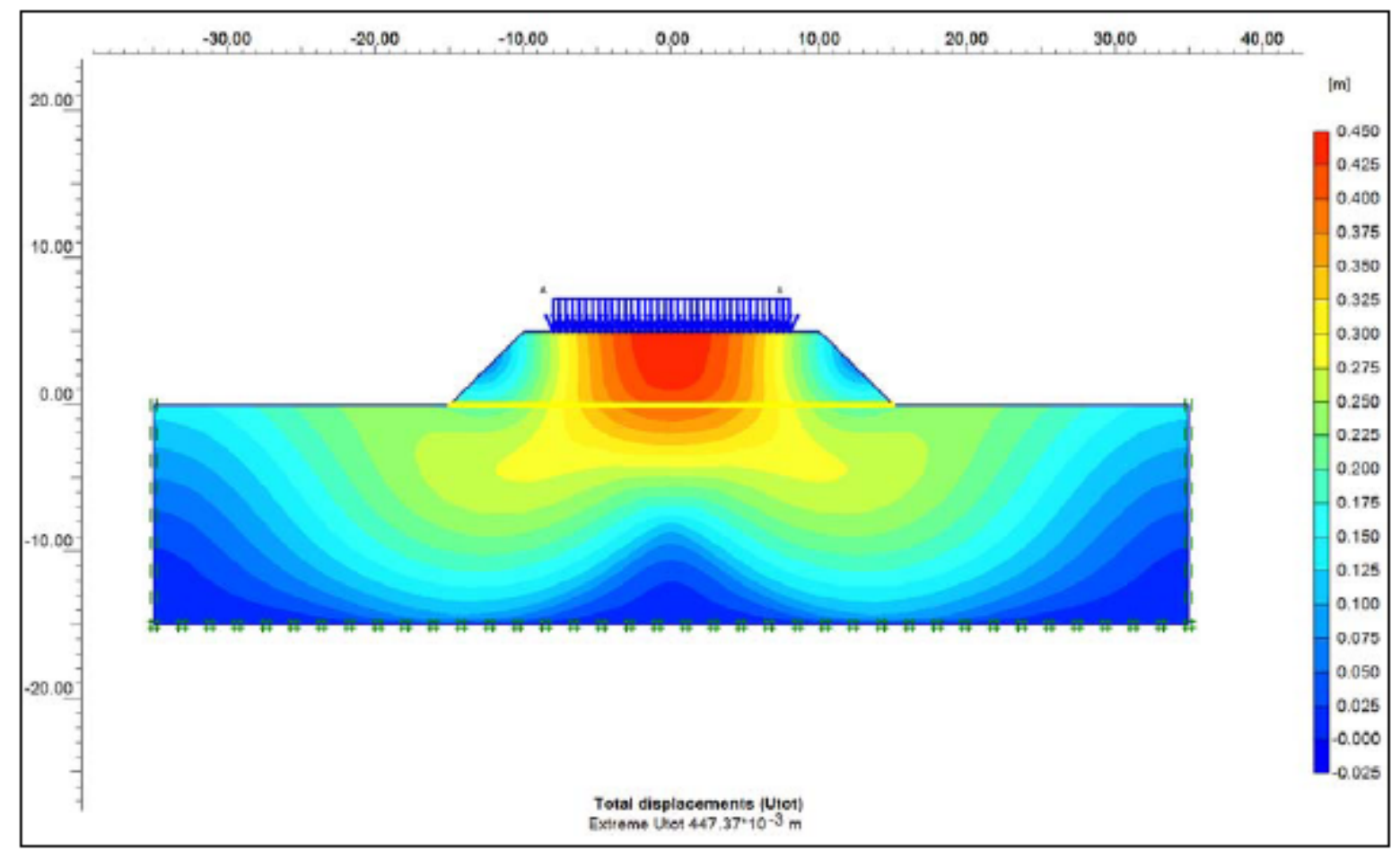

Gambar 9. Pola dan besar displacement konstruksi timbunan tanah laterit.

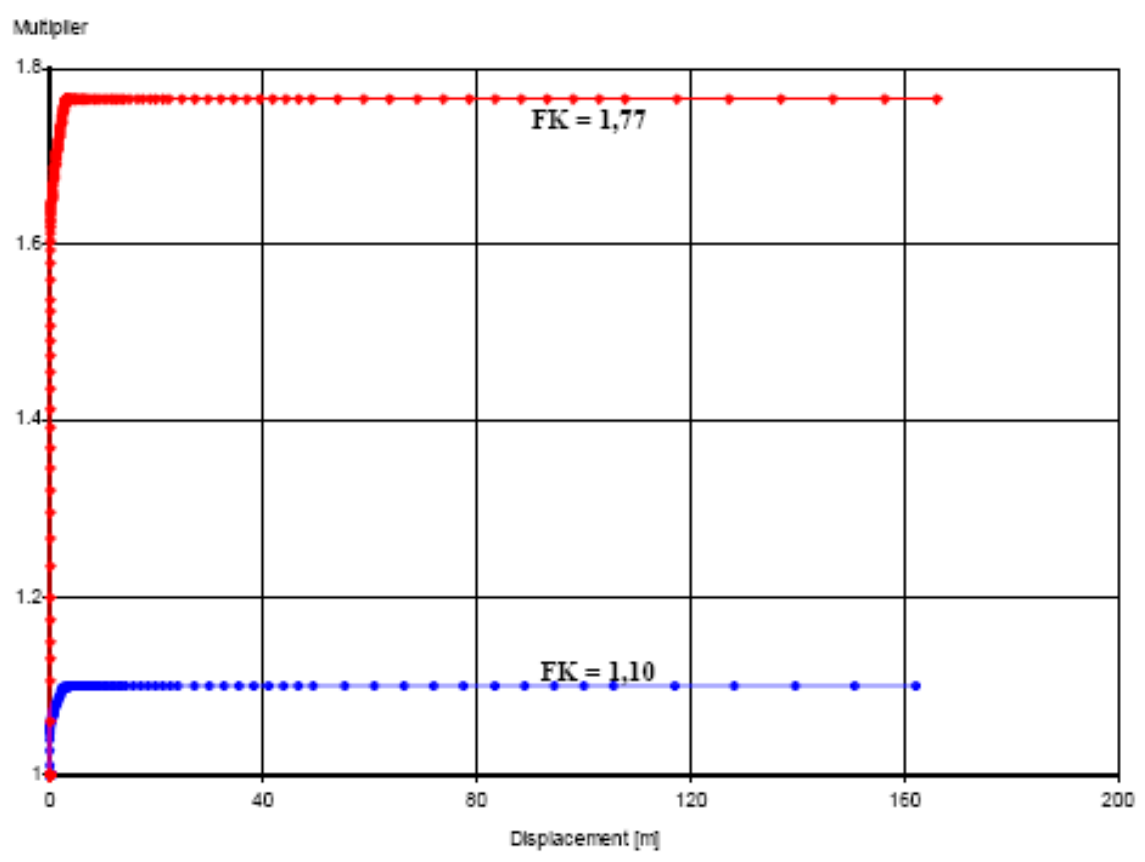

Grafik FK

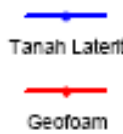

Gambar 10. Grafik faktor keamanan. 


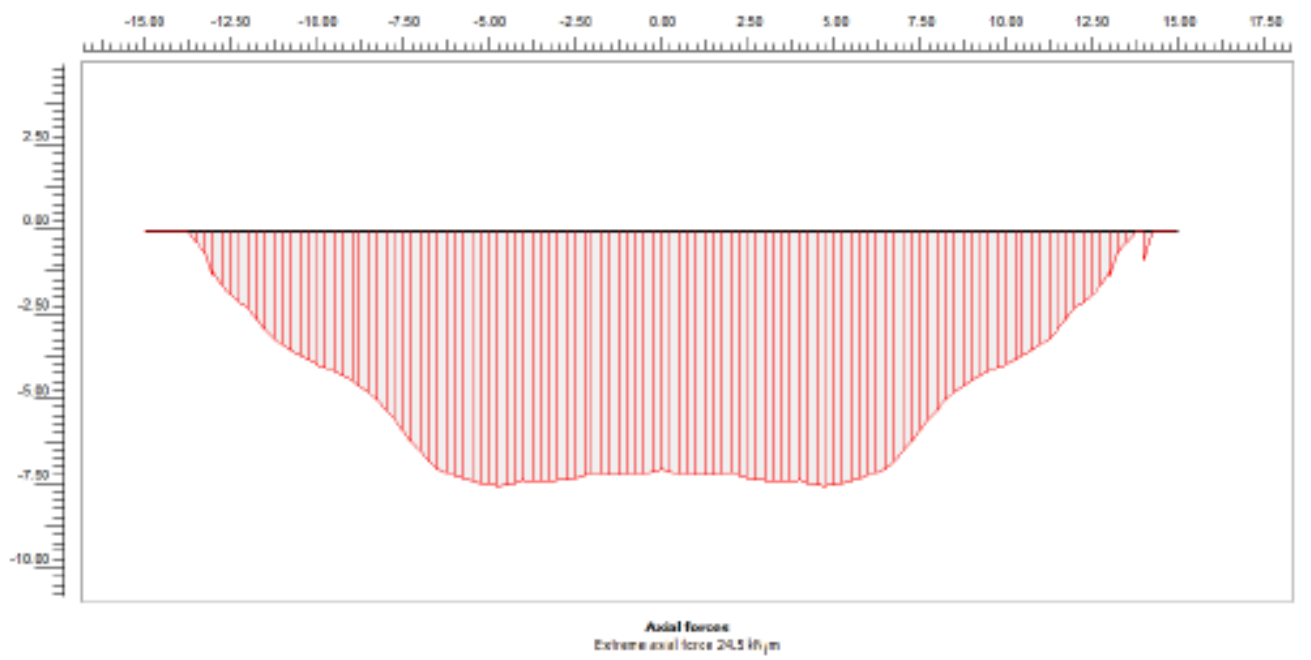

Gambar 11. Kuat tarik perlu geotekstil konstruksi timbunan geofoam

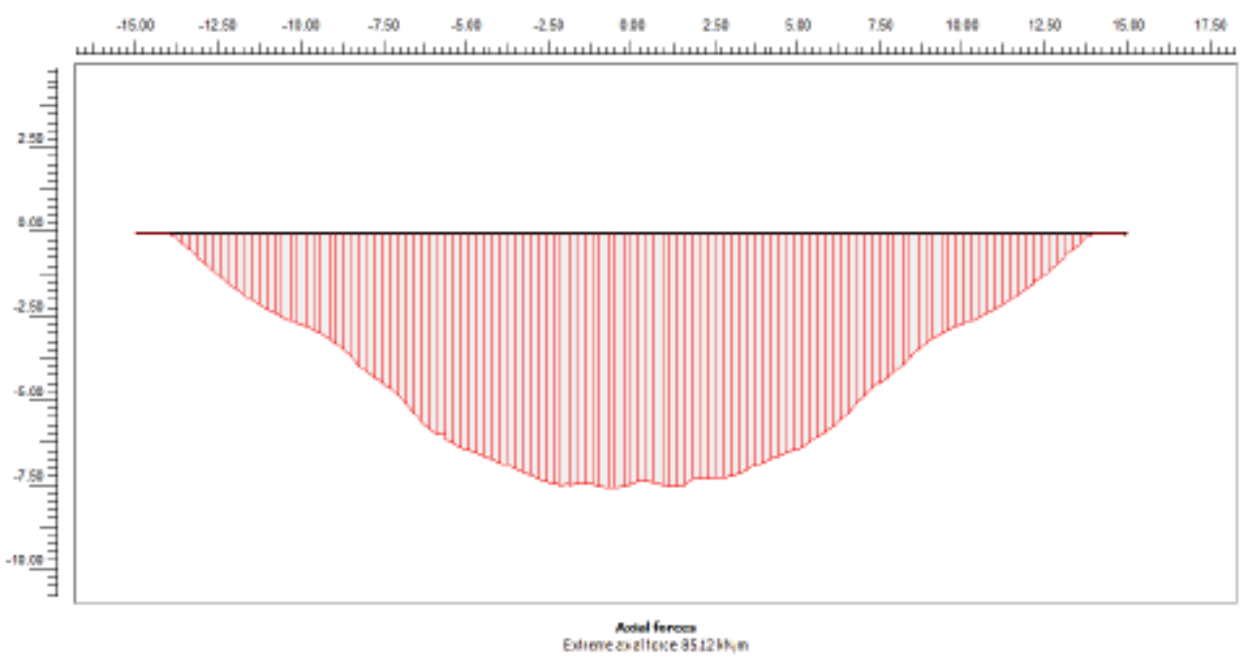

Gambar 12. Kuat tarik perlu geotekstil konstruksi timbunan tanah laterit

\section{PENUTUP}

Berdasarkan hasil perhitungan menggunakan program Plaxis tersebut di atas, dapat ditarik beberapa kesimpulan.

Pertama, penggunaan geofoam sebagai material pengisi timbunan memberikan beberapa keuntungan jika dibandingkan dengan timbunan menggunakan tanah laterit, yaitu:

(1) Faktor keamanan yang lebih tinggi

Geofoam, $\mathrm{FK}=1,77$

Tanah laterit, $\mathrm{FK}=1,10$

(2) Deformasi yang lebih rendah

Geofoam, displacement $=200,5 \mathrm{~mm}$

Tanah laterit, displacement $=447,4 \mathrm{~mm}$ 
(3) Kuat tarik geotekstil yang lebih rendah

Geofoam, $\mathrm{P}_{\text {req }}=24,5 \mathrm{kN} / \mathrm{m}$

Tanah laterit, $\mathrm{FK}=85,12 \mathrm{kN} / \mathrm{m}$

Kedua, keunggulan material geofoam termasuk daya tahan material serta dapat didaur ulang harus dapat dimanfaatkan untuk meningkatkan kualitas konstruksi timbunan di atas tanah lunak.

Ketiga, penelitian ini perlu dikaji lebih lanjut termasuk uji skala penuh di lapangan guna mendapatkan hasil yang lebih memuaskan.

\section{DAFTAR PUSTAKA}

Arrelano, D. (2010). Preliminary Design Procedure for Eps-Block Geofoam Lightweight Fill in Levees Overlying Soft Ground. 27th Annual Association of State Dam Safety Officials Conference. Tennessee: University of Memphis.

Geofoam Research Center. (2011). Geofoam Research Center website. Diakses dari http://geofoam.syr.edu.

GeoTech Systems Corporation. GeoTech TerraLite EPS Geofoam. Diakses dari http://www.geosyscorp.com/noframes/products/terralite.htm

Holtz, R.D. and Schuster, R.L., (1996). Stabilization of Soil Slopes. In: Landslides Investigation and Mitigation. Transportation Research Board Special Report, (247) (p. 429-473). Washington D.C.: National Academy Press.

Humphrey, D.N., Dunn, P.A., \& Merfeld, P.S. (2000). Tire Shreds Save Money for Maine. TR News, (206). Diakses dari http://onlinepubs.trb.org/onlinepubs/trnews/rpo/rpo.trn206.pdf.

Laudontech. Diakses dari http://laudontech.com

Rygg, N., Sorlie, A., (1981). Plastic Foam in Road Embankments. Stockholm: Soil Mechanics Conference. 